\title{
Overlap in utilization of juvenile Cape horse mackerel by Cape fur seals and the purse-seine fishery in Namibia
}

\author{
Silvia Mecenero ${ }^{1 *}$, Les G. Underhill', Jens-Otto Krakstad ${ }^{2}$, \\ Stephen P. Kirkman' \& Jean-Paul Roux ${ }^{3}$ \\ ${ }^{1}$ Avian Demography Unit, Department of Staistical Sciences, University of Cape Town, Rondebosch, 7701 South Africa \\ ${ }^{2}$ Institute of Marine Research, P.O. Box 1870 Nordnes, 5817, Bergen, Norway \\ ${ }^{3}$ Lüderitz Marine Research, Ministry of Fisheries and Marine Resources, Lüderitz, Namibia \\ Received 31 July 2006. Accepted 22 November 2006
}

\begin{abstract}
The Cape horse mackerel Trachurus trachurus capensis is one of Namibia's most valuable fish stocks, and an important component to the diet of Cape fur seals, Arctocephalus pusillus pusillus, off northern Namibia. The level of overlap in the utilization of this resource between seals and the purse-seine fishery was investigated using two overlap indices. For high overlap measures, seals and the purse-seine fishery utilized age-2 horse mackerel. For low overlap measures, seals mainly consumed age- 0 fish whereas the fishery caught age-2 fish. Both indices were adjusted by the proportion of horse mackerel in the seal diet, with the assumption that the proportion consumed by the seals reflects the abundance of horse mackerel in the coastal waters of Cape Cross, Namibia. Both unadjusted and adjusted overlap indices showed that overlap between seals and the fishery in their utilization of juvenile horse mackerel was high only at times when horse mackerel abundance was high, and low when abundance was small. Confidence intervals and significance testing were included. Overall, there was little overlap between seals and the purse-seine fishery. This study provides important information that should be taken into account in the management of the horse mackerel resource.
\end{abstract}

Key words: Cape fur seal, Arctocephalus pusillus pusillus, Cape horse mackerel, Trachurus trachurus capensis, Namibia, fishery, diet overlap.

\section{INTRODUCTION}

The northern Benguela System along the coast of Namibia is highly productive (Currie 1953), comprising part of one of the four major eastern boundary upwelling centres in the world (Shannon \& Jarre-Teichmann 1999). It sustains prey required by top predators such as marine birds and mammals, and its resources are exploited by the Namibian fishing industry (Boyer \& Hampton 2001). Certain commercial fish resources are shared between marine top predators and fisheries. For example, the Cape fur seal (Arctocephalus pusillus pusillus) consumes commercially important fish such as Cape hakes (Merluccius spp.), Cape horse mackerel (Trachurus trachurus capensis), sardine (Sardinops sagax) and anchovy (Engraulis encrasicolus) (David 1987; Mecenero et al. 2006a). For this reason, and the fact that seals are amongst the most visible of the top predators in the system, fishers consider Cape

\footnotetext{
*To whom correspondence should be addressed.
} E-mail: smecener@adu.uct.ac.za fur seals to be their main competitors for fish stocks (Wickens et al. 1992).

The Cape horse mackerel is the most commercially exploited fish resource in Namibian waters, in terms of mass (Axelsen et al. 2004). This resource has been exploited by the purse-seine fishery since 1971 (Boyer \& Hampton 2001). The fishery targets juveniles (12.5-20 cm in length) inshore of the $200 \mathrm{~m}$ isobath (Bauleth-D'Almeida et al.2001) and focuses its attention on the northern coast of Namibia (Krakstad \& Kanandjembo 2001; Axelsen et al.2004) where large concentrations of juvenile horse mackerel are found (O'Toole 1977; Krakstad \& Kanandjembo 2001). Juveniles are targeted by the purse-seine fleet mainly up to Cape Frio $\left(18^{\circ} 26^{\prime} S\right)$, and less often up to the border with Angola ( $\left.17^{\circ} \mathrm{S}\right)$. Cunene horse mackerel ( $T$. trecae) is only rarely present in the catches, and the proportion is always very low (NatMIRC, unpubl. data). Horse mackerel purse-seiners catch most of their fish during the first half of the year when the fish occur in dense schools, making 
them easier to catch, and when quota limits have not yet been reached.

One of the largest Cape fur seal breeding colonies is found at Cape Cross, in northern Namibia. It has a population of about 187000 seals, approximately $30 \%$ of Namibia's seal population (Marine and Coastal Management (MCM), South Africa, unpubl. data 2006). Prey hard parts retrieved from scats collected from 1994 to 2001 indicated that horse mackerel are an important component of the diet of seals from this colony, particularly during the first half of the year (Mecenero et al. 2006a,b). Horse mackerel was also the prey item most frequently found in the stomachs of seals collected off northern Namibia during research cruises between 1975 and 1979 (Shaughnessy 1985). The possibility therefore exists that Namibia's purse-seine fishery and the Cape Cross seals share the horse mackerel resource.

Using Schoener's overlap index (Schoener 1970) to compare fishery catch statistics with data from scats collected at Cape Cross, Plarre (1996) found that seals from Cape Cross and the purse-seine fishery overlapped in their utilization of the juvenile horse mackerel resource by as much as $72 \%$, in a few months of the year. Schoener's overlap index used by Plarre (1996) assumes that all states (classes) of the resource are equally abundant, and is therefore subject to bias in that it ignores the variation in abundance of the horse mackerel classes. Numerous other indices of overlap in resource utilization have been proposed in recent decades (e.g. Lloyd 1967; Schoener 1970; Pianka 1973; Hurlbert 1978; Petraitis 1979), but each has its own limitations (Hurlbert 1978; Petraitis 1979; Abrams 1980; Ricklefs \& Lau 1980; Smith \& Zaret 1982).

The aim of this study was to measure the overlap between seals and the purse-seine fishery with regard to their utilization of juvenile horse mackerel off the shore of northern Namibia, using seal scats collected at the Cape Cross colony and records of fishery catches. This study expands on the work of Plarre (1996) because: (1) it is based on eight years of diet and catch data as opposed to two, (2) it compares the findings of two overlap indices, (3) it includes confidence intervals and significance testing derived from randomization and bootstrapping methods (Manly 1991). Investigating overlap in the utilization of a fish resource by seals and a fishery can provide information on the interactions between seals and fisheries that is important for fish stock management decisions.

\section{MATERIALS AND METHODS}

\section{Seal scat collection and processing}

The collection and processing of scats is described in Mecenero et al. (2006a). Briefly, fresh seal scat samples were collected at the Cape Cross seal colony $\left(21^{\circ} 47^{\prime} \mathrm{S}, 13^{\circ} 57^{\prime} \mathrm{E}\right)$ in northern Namibia from January 1994 to December 2001. The scats from this breeding colony mainly represent those of lactating female fur seals. Sampling was designed to be at monthly intervals, but no scats were collected in 22 of the 96 months. Samples consisted of 30-60 scats pooled together as a 'bag' sample. Where more than one sample was collected in a month, they were pooled to represent that month. Samples were rinsed with running water and passed through nested stainless steel laboratory test sieves with apertures of 2.0, 1.0, 0.425 and $0.212 \mathrm{~mm}$. The rinsed material was dried overnight in an oven $\left(50^{\circ} \mathrm{C}\right)$.

Teleost sagittal otoliths were sorted from the dried matter, identified to the lowest possible taxon, and counted. Six teleost groups were identified (hake, horse mackerel, pelagic goby (Sufflogobius bibarbatus), lanternfish (Myctophidae), pelagics and others; Mecenero et al. 2006a). The diameters of otoliths from subsamples of each sample (c. 200 otoliths per sample) were measured to the closest $0.05 \mathrm{~mm}$ for each teleost group (see Mecenero et al. 2006a). Otolith numbers were corrected for numbers lost, and otolith diameters were corrected for erosion during digestion (correction factors were determined by captive feeding trials on Cape fur seals, D.L. Millar et al. unpubl. data 1996, MCM; see Mecenero et al. 2006a for a full account on the correction factors used). Corrected otolith diameters were converted to fish lengths using relationships between otolith diameter and fish length (Smale et al. 1995; see Mecenero et al. 2006a). Length-frequencies of horse mackerel consumed by seals were determined at $0.5 \mathrm{~cm}$ class intervals. A horse mackerel age-length key was used to age the fish in the seal diet (Anon. 2000). The percentage abundance of each main teleost group identified was calculated as the total number of that group in a sample expressed as a percentage of the total number of all teleost prey groups in the sample (Mecenero et al. 2006a). Thus, the relative abundance of horse mackerel in the seal diet was determined for each monthly sample.

Biases associated with scat analysis were 
reviewed by Pierce \& Boyle (1991). The main bias is that otoliths are partially or even completely eroded during the digestion process, affecting abundance and fish length estimates of teleost prey from the scats (Dellinger \& Trillmich 1988; Orr \& Harvey 2001; Staniland 2002). However, this study corrected for the partial or complete erosion of otoliths by using correction factors. Despite these biases, scat analysis can provide valuable information on prey consumption (Tollit \& Thompson 1996).

\section{Purse-seine catches}

The purse-seine fishery for horse mackerel was most active between February and April of each year and no fishing occurred from August to December or mid-January. The upper limit of the catches did not exceed predetermined quotas. Random samples of 50 fish were taken from landed purse-seine catches and the total length of each fish was measured to the nearest $0.5 \mathrm{~cm}$ (Bauleth-D'Almeida et al.2001). A horse mackerel age-length key was used to age the fish in the fishery catches (Anon. 2000). Data for the years 1994 to 2001 were used in this study.

Only purse-seine catches made within latitudes $20-24^{\circ} \mathrm{S}$, and between $12^{\circ} \mathrm{E}$ and the coast were used. This approximates a $200 \mathrm{~km}$ foraging radius from Cape Cross. This radius was decided upon because in $99 \%$ of foraging trips by satellitemonitored adult females $(n=17)$ between 2002 and 2004, the distance from Cape Cross to the foraging area where maximum time was spent was within $200 \mathrm{~km}$ of the coast (SPK). Of 768 hauls between 1994 and 2001, 547 occurred within this area. When more than one catch was landed during a month, measurements from each catch were pooled to represent that month. Lengthfrequencies of horse mackerel caught were determined at $0.5 \mathrm{~cm}$ class intervals.

\section{Measurement of overlap}

Schoener's (1970) and Morisita's (1959) indices were used to examine overlap in the utilization of juvenile horse mackerel by Cape fur seals and the purse-seine fishery in northern Namibia. Schoener's overlap index (S) was included as it had been used during the only previous investigation of overlap in horse mackerel utilization by Cape fur seals and the purse-seine fishery (Plarre 1996):

$$
S=1-1 / 2\left(\sum_{i=1}^{r}\left|P_{s i}-P_{f i}\right|\right),
$$

where $i=1, \ldots L, r$ is the number of resource states, in this case the number of $0.5 \mathrm{~cm}$ length classes of horse mackerel from 0-33.0 cm, thus $r=66 ; p_{s i}=$ $n_{s i} / N_{s}$ is the proportion of the resource in state $i$ taken by seals; $p_{f i}=n_{i t} / N_{f}$ is the proportion of the resource in state $i$ taken by the fishery; $n_{s i}$ and $n_{t i}$ are the numbers of horse mackerel in resource state $i$ taken by seals and the fishery, respectively; $N_{s}=\sum_{i=1}^{r} n_{s i}$ and $N_{f}=\sum_{i=1}^{r} n_{f i} . S$ ranges in value from zero (no overlap) to one (complete overlap).

Morisita's index $(M)$ of overlap was also employed in this study as it was shown by Smith and Zaret (1982), in a comparative study of seven overlap indices, to be the least biased by sample size and the number of resource states:

$$
M=\frac{2 \sum_{i=1}^{r} p_{s i} P_{f i}}{\sum_{i=1}^{r} P_{s i} \frac{n_{s i}-1}{N_{s}-1}+\sum_{i=1}^{r} P_{f i} \frac{n_{f i}-1}{N_{f}-1}},
$$

where the variables are defined as for Schoener's index. $M$ ranges in value from zero (no overlap) to one (complete overlap).

Some studies have shown that the proportion of a prey species or its length classes in the diet of a predator reflects the abundance of that prey species or its length classes (Crawford et al. 1992; Klages et al. 1992; Montevecchi \& Myers 1995; Hunt et al. 1996; Reid et al. 1999). Accordingly, in order to integrate prey abundance into overlap indices, which is one of the requirements for understanding competitive interactions between predators (Harwood \& Croxall 1988), Schoener's and Morisita's overlap indices were adjusted $\left(S_{a d j}\right.$ and $M_{a d j}$, respectively) by multiplying with the proportion of horse mackerel abundance in the diet of Cape fur seals, with the assumption that the proportion consumed by the seals reflects the abundance of horse mackerel in the coastal waters of Cape Cross:

$$
\begin{aligned}
& S_{a d j}=S \times \text { (proportion of horse mackerel } \\
& \text { abundance in the seal diet). } \\
& M_{\text {adj }}=M \times \text { (proportion of horse mackerel } \\
& \text { abundance in the seal diet). }
\end{aligned}
$$

The above-mentioned overlap measures $(S, M$, $S_{a d j}$ and $M_{a d j}$ ) were determined for months where resource utilization data for both seals and the fishery existed, from 1994 and 2001 (34 months). In the absence of appropriate precedents in the literature, 0.25 (and less) and 0.75 (and more) 
were arbitrarily adopted as low and high levels of overlap, respectively, between seals and the purse-seine fishery for the utilization of horse mackerel.

\section{Confidence intervals and randomization tests for overlap indices}

Confidence intervals for $S$ and $M$ were determined using the bootstrap procedure (Ricklefs \& Lau 1980; Manly 1991). Bootstrap samples ( $n=$ 10000 , sampling with replacement) were taken from the original samples of horse mackerel in the seal diet and purse-seine fishery, with the size of each bootstrap sample equal to the original sample, for each month where both sets of data existed. From these, 10000 estimates of the overlap measure were determined for each month. The 10000 estimates were arranged in increasing order, and the 95\% confidence intervals were determined by taking the 250th and the 9750th values. To obtain confidence intervals for $S_{\text {adj }}$ and $M_{a d j}$, the confidence intervals for $S$ and $M$ were multiplied by the proportion of horse mackerel abundance in the diet of Cape fur seals for the corresponding months.

In order to test the null hypothesis $\left(\mathrm{H}_{0}\right)$ that the observed overlap measure could have originated from a distribution of fish lengths that was the same for both seals and fisheries, randomization methods were used (Manly 1991). In randomization tests (as in all statistical hypothesis testing), the null hypothesis states that some feature of interest is absent from the observed data. A test statistic is devised which measures the extent to which the data departs from this feature. The test statistic is computed first for the observed data. Thereafter, the test statistic is computed for many thousands of random permutations of the observed data, and the distribution of the test statistic is obtained. If the value of the test statistic obtained from the observed data lies in the tails of this distribution, the null hypothesis is rejected.

In this case, $S$ and $M$ were used as the test statistics. The overlap measure for the observed data was denoted $S_{1}$ or $M_{1}$, respectively. For each of the 34 months for which both seal diet data and purse-seine fishery data were available, the lengths of the horse mackerel sub-samples of seal diet and fishery data were pooled. The observed data for month $m\left(n_{s i}+n_{f i}\right.$ observations) were randomly permuted 10000 times using an algorithm provided by Manly (1991). The first $n_{s i}$ observations were assigned to the seals and the remaining $n_{f i}$ to the fishery. The overlap measures $S$ and $M$ were computed for each randomization of the data. A count was kept of the number of times the values of $S$ and $M$ were greater than or equal to $S_{1}$ and $M_{1}$, respectively. This count, divided by 10000 , estimates the significance level of the test. If it is less than 0.05 , the null hypothesis is rejected at the $5 \%$ significance level. Manly (1991) has provided a philosophical discussion of randomization tests, and their applicability to these kinds of data.

\section{RESULTS}

Except for 1998, the resource utilization curve of the purse-seine fishery fell within that of the seals (Fig. 1). Seals consumed smaller length classes more frequently than those caught by the purseseine fishery. For both seals and fishery, there were annual differences in the lengths of horse mackerel consumed or caught (Fig. 1). Five main modes (age classes) of horse mackerel length were observed, and the length values of these main modes varied between the 34 months used in this study. Age-0 was represented by modes ranging between 5.25 and $7.75 \mathrm{~cm}$, age-1 by modes ranging between 8.75 and $11.75 \mathrm{~cm}$, age-2 by modes ranging between 14.75 and $16.75 \mathrm{~cm}$, age- 3 by modes ranging between 20.25 and $22.25 \mathrm{~cm}$, and age- 4 by the mode $24.75 \mathrm{~cm}$.

For each month, the overlap measures of $S$ and $M$ were similar ( $r=0.98$; Table 1$)$. The degree of overlap varied between months; generally, overlap was greatest $(>0.75)$ within the period February to June, and least $(<0.25)$ in January and within the period March to September (Table 1). Where overlap measures were greater than 0.75 , seals and fisheries mainly overlapped in the utilization of age-2 horse mackerel (Fig. 2). In the instances where overlap was less than 0.25 , seals were consuming age- 0 horse mackerel whereas the fishery was catching mainly age-2 horse mackerel (Fig. 3).

There was no correlation between the proportion of horse mackerel in the seal diet and either $S$ or $M$ measures of overlap $(r=0.21$ and 0.13 , respectively, $P>0.05, n=34$ ). However, where the measures of overlap exceeded 0.50 , the percentage of horse mackerel in the teleost component of the seal diet was usually $70 \%$ or more (Table 1 ). Where the measures of overlap were below 0.50 , the percentage of horse mackerel in the diet ranged between 0 and $100 \%$, although when overlap measures were below 0.20 , horse mackerel in the diet generally did not exceed $40 \%$ (Table 1 ). 

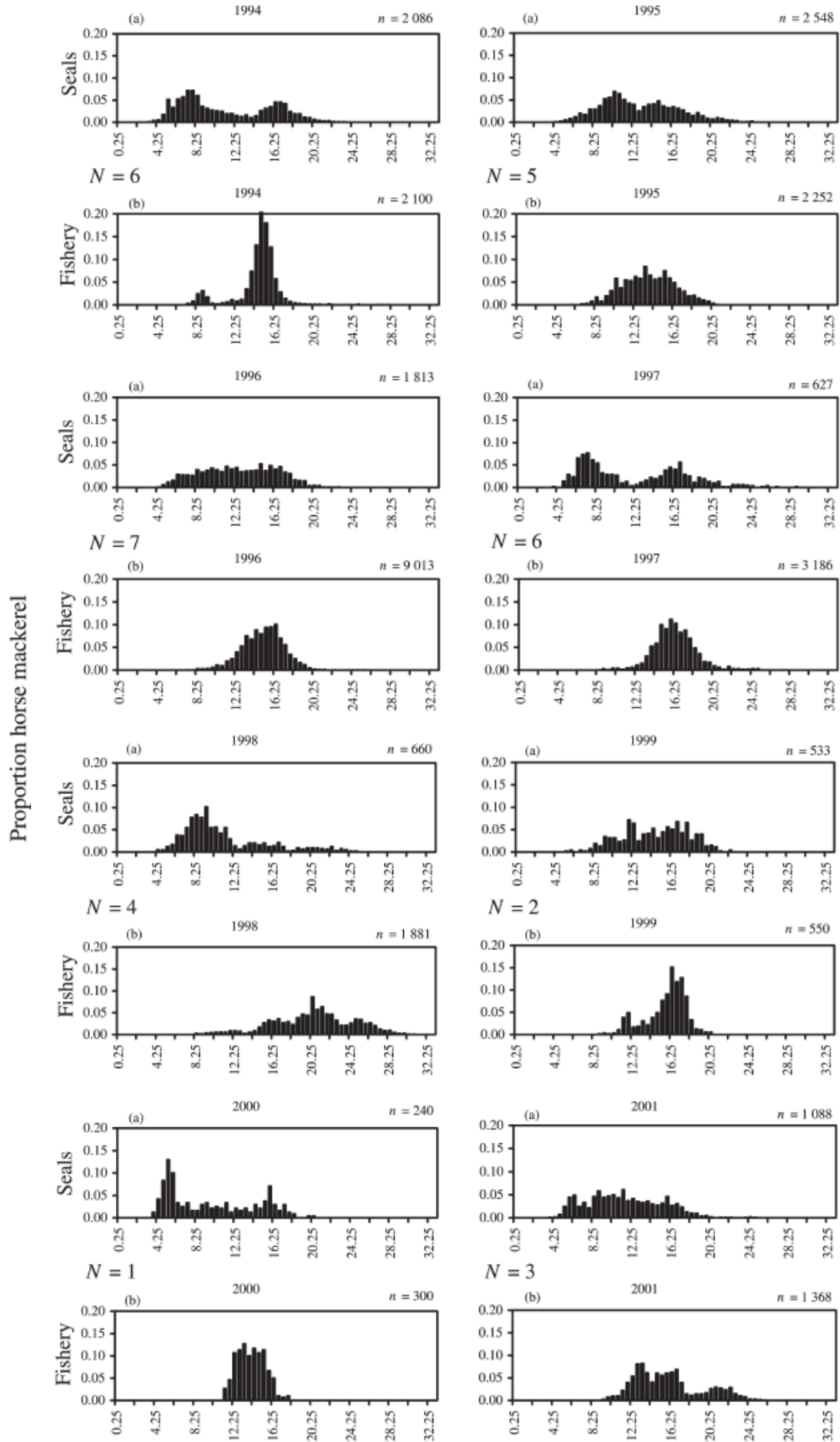

$N=3$

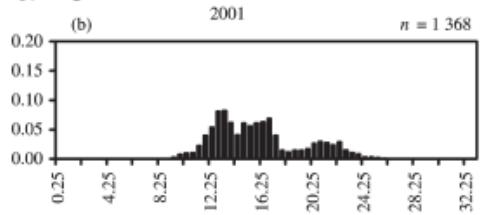

Length class $(\mathrm{cm})$

Fig. 1. Length-frequencies of Cape horse mackerel in (a) the diet of Cape fur seals at Cape Cross and (b) the purse-seine catches within the study area, between 1994 and 2001. The number of otoliths or fish measured is given by $n$, and the number of months for which both seal and fishery resource utilization data was available is given by $N$. 
Table 1. Measures of overlap $\left(S, M, S_{a d j}\right.$ and $\left.M_{a d j}\right)$ in utilization of Cape horse mackerel by Cape fur seals and the purse-seine fishery within the study area. Ninety-five per cent confidence intervals, determined by bootstrapping, are in brackets. Sample sizes of otoliths and individuals sampled from the seal scats and the fishery catches, are represented by $n_{\mathrm{s}}$ and $n_{f}$, respectively. The relative abundance of horse mackerel in the seal diet, expressed as a proportion, is given by NA. Overlap measures for which $\mathrm{H}_{0}$ was accepted $(P>0.05)$ are indicated by an asterisk.

\begin{tabular}{|c|c|c|c|c|c|c|c|}
\hline Date & $n_{s}$ & $n_{f}$ & $S$ & $M$ & NA & $S_{a d j}$ & $M_{a d j}$ \\
\hline Mar 94 & 211 & 250 & $\begin{array}{c}0.45 \\
(0.38-0.52)\end{array}$ & $\begin{array}{c}0.49 \\
(0.38-0.60)\end{array}$ & 0.94 & $\begin{array}{c}0.42 \\
(0.35-0.49)\end{array}$ & $\begin{array}{c}0.46 \\
(0.36-0.56)\end{array}$ \\
\hline Apr 94 & 210 & 323 & $\begin{array}{c}0.40 \\
(0.33-0.47)\end{array}$ & $\begin{array}{c}0.46 \\
(0.36-0.56)\end{array}$ & 0.39 & $\begin{array}{c}0.15 \\
(0.13-0.18)\end{array}$ & $\begin{array}{c}0.18 \\
(0.14-0.22)\end{array}$ \\
\hline May 94 & 474 & 434 & $\begin{array}{c}0.10 \\
(0.08-0.13)\end{array}$ & $\begin{array}{c}0.09 \\
(0.06-0.13)\end{array}$ & 0.37 & $\begin{array}{c}0.04 \\
(0.03-0.05)\end{array}$ & $\begin{array}{c}0.03 \\
(0.02-0.05)\end{array}$ \\
\hline Jun 94 & 520 & 453 & $\begin{array}{c}0.26 \\
(0.22-0.30)\end{array}$ & $\begin{array}{c}0.21 \\
(0.16-0.26)\end{array}$ & 0.44 & $\begin{array}{c}0.11 \\
(0.10-0.13)\end{array}$ & $\begin{array}{c}0.09 \\
(0.07-0.11)\end{array}$ \\
\hline Jul 94 & 394 & 281 & $\begin{array}{c}0.48 \\
(0.42-0.54)\end{array}$ & $\begin{array}{c}0.60 \\
(0.52-0.69)\end{array}$ & 0.07 & $\begin{array}{c}0.03 \\
(0.03-0.04)\end{array}$ & $\begin{array}{c}0.04 \\
(0.04-0.05)\end{array}$ \\
\hline Sep 94 & 277 & 359 & $\begin{array}{c}0.14 \\
(0.10-0.18)\end{array}$ & $\begin{array}{c}0.11 \\
(0.07-0.17)\end{array}$ & 0.06 & $\begin{array}{c}0.01 \\
(0.01-0.01)\end{array}$ & $\begin{array}{c}0.01 \\
(0-0.01)\end{array}$ \\
\hline Mar 95 & 340 & 12 & $\begin{array}{c}0.13 \\
(0.08-0.19)\end{array}$ & $\begin{array}{c}0.22 \\
(0.11-0.35)\end{array}$ & 0.99 & $\begin{array}{c}0.13 \\
(0.08-0.18)\end{array}$ & $\begin{array}{c}0.21) \\
(0.10-0.34\end{array}$ \\
\hline Apr 95 & 308 & 695 & $\begin{array}{c}0.65 \\
(0.59-0.70)\end{array}$ & $\begin{array}{c}0.79 \\
(0.72-0.86)\end{array}$ & 0.91 & $\begin{array}{c}0.59 \\
(0.54-0.64)\end{array}$ & $\begin{array}{c}0.72 \\
(0.65-0.79)\end{array}$ \\
\hline Jun 95 & 1363 & 1419 & $\begin{array}{c}0.75 \\
(0.72-0.78)\end{array}$ & $\begin{array}{c}0.89 \\
(0.86-0.92)\end{array}$ & 0.79 & $\begin{array}{c}0.59 \\
(0.57-0.62)\end{array}$ & $\begin{array}{c}0.70 \\
(0.68-0.72)\end{array}$ \\
\hline Jul 95 & 223 & 40 & $\begin{array}{c}0.39) \\
(0.27-0.51\end{array}$ & $\begin{array}{c}0.52 \\
(0.32-0.73)\end{array}$ & 0.70 & $\begin{array}{c}0.27 \\
(0.19-0.36)\end{array}$ & $\begin{array}{c}0.37 \\
(0.22-0.51)\end{array}$ \\
\hline Aug 95 & 314 & 86 & $\begin{array}{c}0.21 \\
(0.15-0.27)\end{array}$ & $\begin{array}{c}0.23 \\
(0.15-0.32)\end{array}$ & 0.28 & $\begin{array}{c}0.06 \\
(0.04-0.08)\end{array}$ & $\begin{array}{c}0.06 \\
(0.04-0.09)\end{array}$ \\
\hline Feb 96 & 465 & 1228 & $\begin{array}{c}0.52 \\
(0.47-0.56)\end{array}$ & $\begin{array}{c}0.65 \\
(0.59-0.72)\end{array}$ & 0.73 & $\begin{array}{c}0.38 \\
(0.34-0.41)\end{array}$ & $\begin{array}{c}0.48 \\
(0.43-0.52)\end{array}$ \\
\hline Mar 96 & 310 & 3967 & $\begin{array}{c}0.79 \\
(0.74-0.84)\end{array}$ & $\begin{array}{c}0.95 \\
(0.90-0.98)\end{array}$ & 0.79 & $\begin{array}{c}0.62 \\
(0.59-0.66)\end{array}$ & $\begin{array}{c}0.75 \\
(0.71-0.77)\end{array}$ \\
\hline Apr 96 & 211 & 1679 & $\begin{array}{c}0.67 \\
(0.61-0.73)\end{array}$ & $\begin{array}{c}0.83 \\
(0.75-0.90)\end{array}$ & 0.77 & $\begin{array}{c}0.52 \\
(0.47-0.56)\end{array}$ & $\begin{array}{c}0.64 \\
(0.58-0.69)\end{array}$ \\
\hline May 96 & 205 & 1985 & $\begin{array}{c}0.45 \\
(0.39-0.51)\end{array}$ & $\begin{array}{c}0.56 \\
(0.47-0.66)\end{array}$ & 0.77 & $\begin{array}{c}0.35 \\
(0.30-0.39)\end{array}$ & $\begin{array}{c}0.43 \\
(0.36-0.50)\end{array}$ \\
\hline Jun 96 & 223 & 52 & $\begin{array}{c}0.43 \\
(0.33-0.53)\end{array}$ & $\begin{array}{c}0.55 \\
(0.39-0.71)\end{array}$ & 0.15 & $\begin{array}{c}0.06 \\
(0.05-0.08)\end{array}$ & $\begin{array}{c}0.08 \\
(0.06-0.11)\end{array}$ \\
\hline Jul 96 & 200 & 50 & $\begin{array}{c}0.44 \\
(0.35-0.53)\end{array}$ & $\begin{array}{c}0.59 \\
(0.44-0.74)\end{array}$ & 0.01 & $\begin{array}{c}0 \\
(0-0.01)\end{array}$ & $\begin{array}{c}0.01 \\
(0-0.01)\end{array}$ \\
\hline Aug 96 & 199 & 52 & $\begin{array}{c}0.43 \\
(0.35-0.51)\end{array}$ & $\begin{array}{c}0.61 \\
(0.47-0.74)\end{array}$ & 0.07 & $\begin{array}{c}0.03 \\
(0.02-0.04)\end{array}$ & $\begin{array}{c}0.04 \\
(0.03-0.05)\end{array}$ \\
\hline Jan 97 & 23 & 1988 & $\begin{array}{c}0.04 \\
(0-0.08)\end{array}$ & $\begin{array}{c}0.04 \\
(0-0.13)\end{array}$ & 0.02 & $\begin{array}{c}0.001 \\
(0-0.002)\end{array}$ & $\begin{array}{c}0.001 \\
(0-0.003)\end{array}$ \\
\hline Feb 97 & 112 & 660 & $\begin{array}{c}0.72^{*} \\
(0.64-0.79)\end{array}$ & $\begin{array}{c}0.93^{*} \\
(0.84-0.99)\end{array}$ & 0.06 & $\begin{array}{c}0.04 \\
(0.04-0.05)\end{array}$ & $\begin{array}{c}0.06 \\
(0.05-0.06)\end{array}$ \\
\hline Mar 97 & 200 & 449 & $\begin{array}{c}0.59 \\
(0.52-0.66)\end{array}$ & $\begin{array}{c}0.80 \\
(0.71-0.88)\end{array}$ & 0.19 & $\begin{array}{c}0.11 \\
(0.10-0.13)\end{array}$ & $\begin{array}{c}0.15 \\
(0.13-0.17)\end{array}$ \\
\hline Apr 97 & 201 & 27 & 0 & 0 & 0.94 & 0 & 0 \\
\hline May 97 & 47 & 37 & $\begin{array}{c}0.25 \\
(0.13-0.37)\end{array}$ & $\begin{array}{c}0.29 \\
(0.11-0.54)\end{array}$ & 0.02 & $\begin{array}{c}0.01 \\
(0-0.01)\end{array}$ & $\begin{array}{c}0.01 \\
(0-0.01)\end{array}$ \\
\hline
\end{tabular}


Table 1 (continued)

\begin{tabular}{|c|c|c|c|c|c|c|c|}
\hline Date & $n_{s}$ & $n_{f}$ & $S$ & $M$ & NA & $S_{a d j}$ & $M_{a d j}$ \\
\hline Jul 97 & 44 & 25 & $\begin{array}{c}0.07 \\
(0-0.16)\end{array}$ & $\begin{array}{c}0.07 \\
(0-0.22)\end{array}$ & 0.02 & $\begin{array}{c}0.001 \\
(0-0.003)\end{array}$ & $\begin{array}{c}0.001 \\
(0-0.004)\end{array}$ \\
\hline Jan 98 & 198 & 1518 & $\begin{array}{c}0.27 \\
(0.21-0.33)\end{array}$ & $\begin{array}{c}0.23 \\
(0.16-0.31)\end{array}$ & 0.73 & $\begin{array}{c}0.20 \\
(0.16-0.24)\end{array}$ & $\begin{array}{c}0.17 \\
(0.11-0.23)\end{array}$ \\
\hline Feb 98 & 230 & 160 & $\begin{array}{c}0.26 \\
(0.20-0.31)\end{array}$ & $\begin{array}{c}0.28 \\
(0.19-0.38)\end{array}$ & 0.83 & $\begin{array}{c}0.21 \\
(0.16-0.26)\end{array}$ & $\begin{array}{c}0.23 \\
(0.16-0.31)\end{array}$ \\
\hline Mar 98 & 22 & 199 & $\begin{array}{c}0.19 \\
(0.11-0.27)\end{array}$ & $\begin{array}{c}0.25 \\
(0.12-0.41)\end{array}$ & 0.02 & $\begin{array}{c}0.004 \\
(0-0.01)\end{array}$ & $\begin{array}{c}0.01 \\
(0-0.01)\end{array}$ \\
\hline Apr 98 & 210 & 4 & $\begin{array}{c}0.07 \\
(0.02-0.11)\end{array}$ & $\begin{array}{c}0.16 \\
(0.05-0.38)\end{array}$ & 0.21 & $\begin{array}{c}0.01 \\
(0.01-0.02)\end{array}$ & $\begin{array}{c}0.03 \\
(0.01-0.08)\end{array}$ \\
\hline Mar 99 & 232 & 350 & $\begin{array}{c}0.66 \\
(0.59-0.73)\end{array}$ & $\begin{array}{c}0.81 \\
(0.71-0.89)\end{array}$ & 0.70 & $\begin{array}{c}0.46 \\
(0.41-0.51)\end{array}$ & $\begin{array}{c}0.56 \\
(0.49-0.62)\end{array}$ \\
\hline Apr 99 & 301 & 200 & $\begin{array}{c}0.47 \\
(0.41-0.54)\end{array}$ & $\begin{array}{c}0.61 \\
(0.51-0.70)\end{array}$ & 0.82 & $\begin{array}{c}0.39 \\
(0.34-0.44)\end{array}$ & $\begin{array}{c}0.50 \\
(0.41-0.58)\end{array}$ \\
\hline Mar 00 & 240 & 300 & $\begin{array}{c}0.31 \\
(0.25-0.36)\end{array}$ & $\begin{array}{c}0.34 \\
(0.26-0.43)\end{array}$ & 0.35 & $\begin{array}{c}0.11 \\
(0.09-0.13)\end{array}$ & $\begin{array}{c}0.12 \\
(0.09-0.15)\end{array}$ \\
\hline Feb 01 & 383 & 282 & $\begin{array}{c}0.47 \\
(0.41-0.52)\end{array}$ & $\begin{array}{c}0.52 \\
(0.43-0.61)\end{array}$ & 0.95 & $\begin{array}{c}0.44 \\
(0.39-0.50)\end{array}$ & $\begin{array}{c}0.50 \\
(0.41-0.58)\end{array}$ \\
\hline Apr 01 & 475 & 986 & $\begin{array}{c}0.24 \\
(0.20-0.28)\end{array}$ & $\begin{array}{c}0.23 \\
(0.19-0.28)\end{array}$ & 0.89 & $\begin{array}{c}0.21 \\
(0.18-0.25)\end{array}$ & $\begin{array}{c}0.20 \\
(0.16-0.25)\end{array}$ \\
\hline May 01 & 230 & 100 & $\begin{array}{c}0.65^{\star} \\
(0.56-0.73)\end{array}$ & $\begin{array}{c}0.86^{*} \\
(0.73-0.95)\end{array}$ & 0.95 & $\begin{array}{c}0.62 \\
(0.54-0.69)\end{array}$ & $\begin{array}{c}0.81 \\
(0.69-0.91)\end{array}$ \\
\hline
\end{tabular}

When each overlap index was adjusted by the proportion of horse mackerel in the seal diet, none of the $S_{a d j}$ measures were greater than 0.75 , whereas $M_{a d j}$ measures which met this criterion were confined to the period March to May (Table 1). $S_{a d j}$ and $M_{a d j}$ measures less than 0.25 were found in months throughout the entire period January to September (Table 1). Where both $S_{a d j}$ and $M_{a d j}$ measures were greater than 0.50 , then the proportions of horse mackerel in the teleost portion of the seal diet were greater than $70 \%$ (Table 1). For measures less than 0.50 , the proportion of horse mackerel in the seal diet ranged from 0-100\%; a proportion of $44 \%$ or less of horse mackerel in the seal diet always had overlap measures less than 0.20 for both indices (Table 1).

The relationships between the width of the confidence intervals for the overlap measures $\left(S, M, S_{a d i}\right.$ and $\left.M_{a d j}\right)$ and the sample size of horse mackerel taken by seals and the fishery are given in Fig. 4 . The widths of the confidence intervals for $S$ and $M$ were negatively related to the logarithm of seal sample size $(S: r=-0.40, P=0.02, n=34 ; M: r=$ $-0.41, P=0.02, n=34)$ and catch sample size $(S$ : $r=-0.31, P>0.05, n=34 ; M: r=-0.41, P<0.001$, $n=34)$. The widths of the confidence intervals were less than 0.20 for catch sample sizes greater than 450 and for seal sample sizes greater than 390 (Fig. 4). Confidence interval widths for sample sizes in the range of 2000-4000 for the fishery and $500-1300$ for the seals were not available so it was not possible to determine the minimum sample size for confidence interval widths of less than 0.10 (Fig. 4).

Only two months (February 1997 and May 2001) displayed the possibility that the observed overlap measures ( $S$ and $M$ ) could have originated from a distribution of fish lengths that was the same for both seals and fisheries (Table 1).

\section{DISCUSSION}

Niche overlap is the shared use of a resource by two or more species (Colwell \& Futuyma 1971). The intensity of overlap between marine predators and fisheries is strongest if the fishery exploits the principal prey species of a marine predator population which is at its carrying capacity (Lowry \& Frost 1985). The status of the Cape fur seal population in relation to its carrying capacity is unknown. However, the highest levels of overlap between seals at the Cape Cross breeding colony, which are mainly lactating females, and the horse 

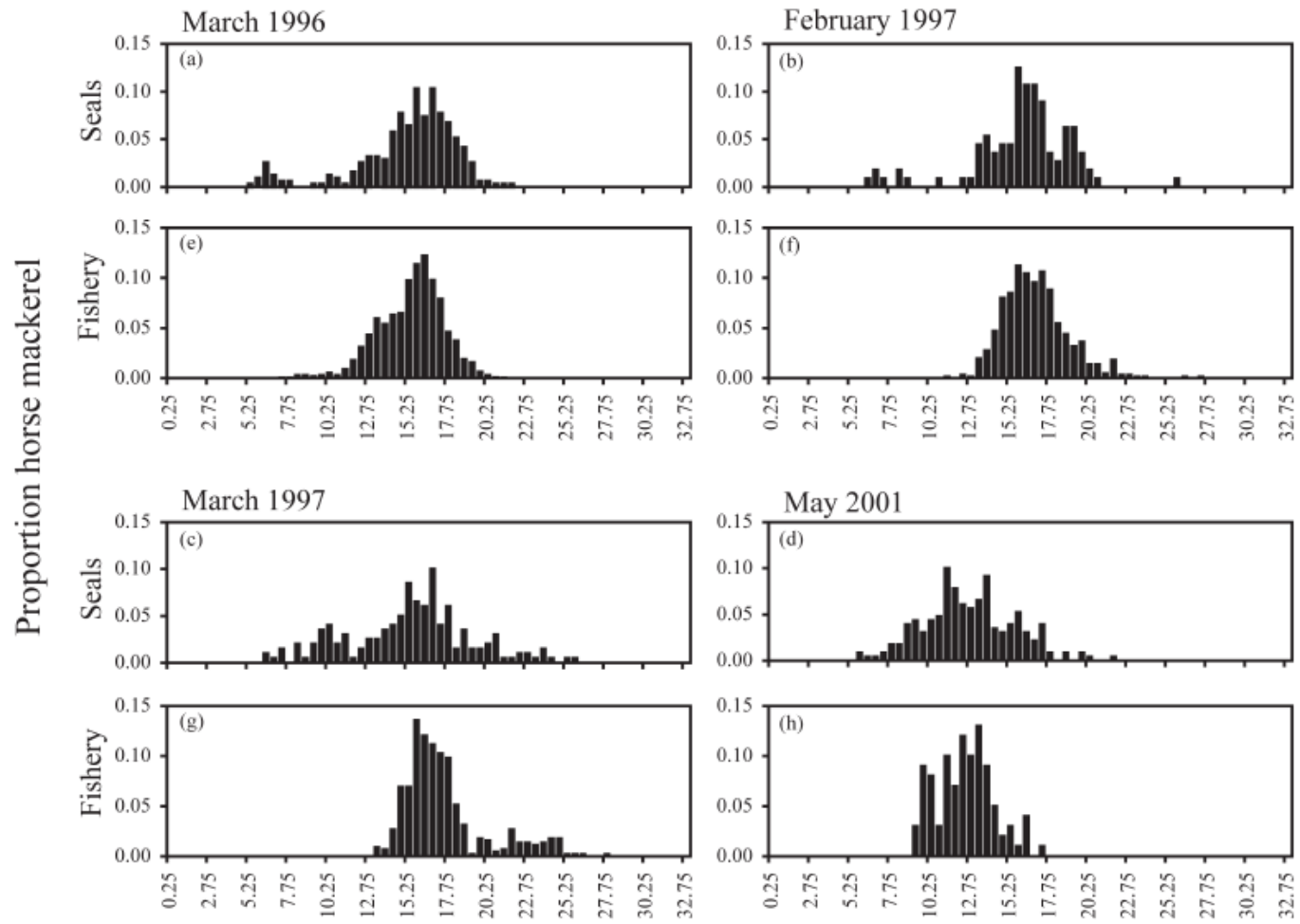

Length class $(\mathrm{cm})$

Fig. 2. Length-frequency distributions for Cape horse mackerel (a-d) consumed by Cape fur seals at Cape Cross and (e-h) caught by the purse-seine fishery within the study area in Namibia, for some months when $M$ was greater than 0.75. Sample sizes, overlap measures $\left(S, M, S_{a d j}\right.$ and $\left.M_{a d j}\right)$ and their confidence intervals are given in Table 1.

mackerel purse-seine fishery occurred from March to May, coinciding with the period when the relative abundance of horse mackerel in the seal diet was highest (Mecenero et al. 2006b).

The degree of overlap between utilizers of a common resource varies according to the accessibility of different resource classes to each. A dietary overlap study between harbour seals Phoca vitulina and great cormorants Phalacrocorax carbo in Sweden and Denmark showed that overlap is higher when the prey resource is most accessible to both predators with regards to foraging habitat type (Härkönen 1988). Juvenile horse mackerel occur in shallow inshore waters (Axelsen et al. 2004), and are thus accessible to seals, which dive to an average depth of $50 \mathrm{~m}$ (Kooyman \& Gentry 1986). The depths targeted by the pure-seine fishery were within the diving range of seals; $86 \%$ of the catches were made within the first $50 \mathrm{~m}$ of depth and $12 \%$ of catches were made at a depth of $50-100 \mathrm{~m}$. Therefore, both seals and the fishery are mainly active in the same habitat type, where horse mackerel are accessible to both, which could lead to high levels of overlap between them.

Additionally, differences in timing of foraging by predators, and differences between the foraging area of seals compared to the area of fishery operations may lead to different resource classes being taken by them (Reid et al. 1996; Dellinger \& Trillmich 1999; Wathne et al. 2000; Goldsworthy et al. 2001). Purse-seiners operate throughout the day and night, and the extent to which Cape fur seals forage at night is unknown although they forage throughout the day (Rand 1959; Punt et al. 1995). Therefore, the influence of the time of foraging on results of this study remains unclear. Purse-seiners do operate outside of the foraging range of lactating seals at Cape Cross, but for the purposes of this study, catches made by purseseine fisheries operating off-shore and out of the seal foraging range were not considered, to overcome the effect of different areas of resource utilization between seals and the fishery. 

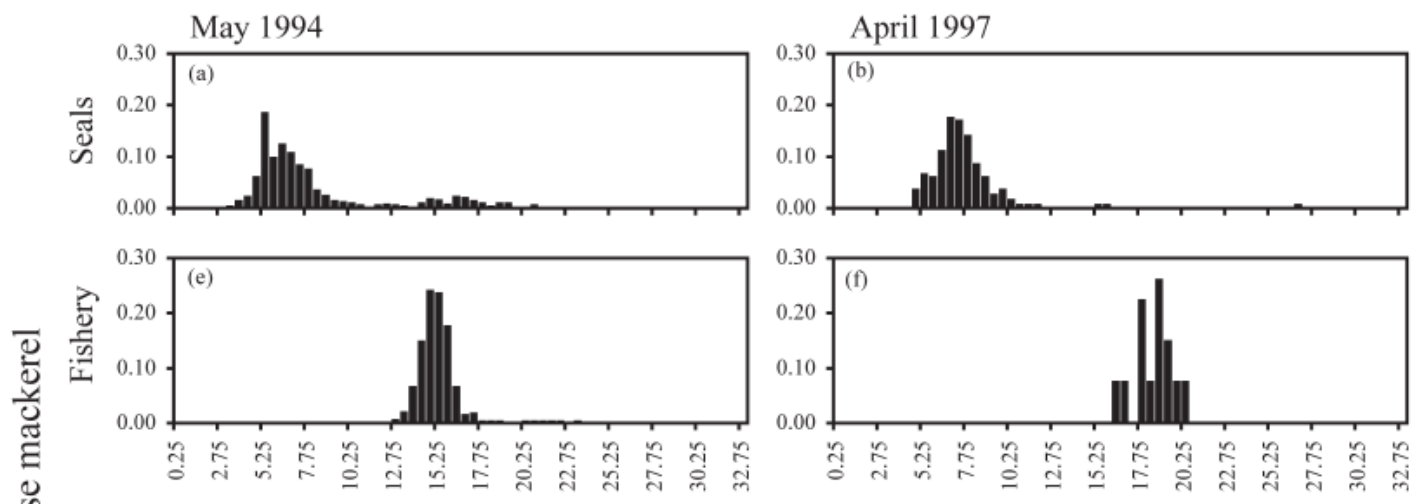

ํㅡㅇ
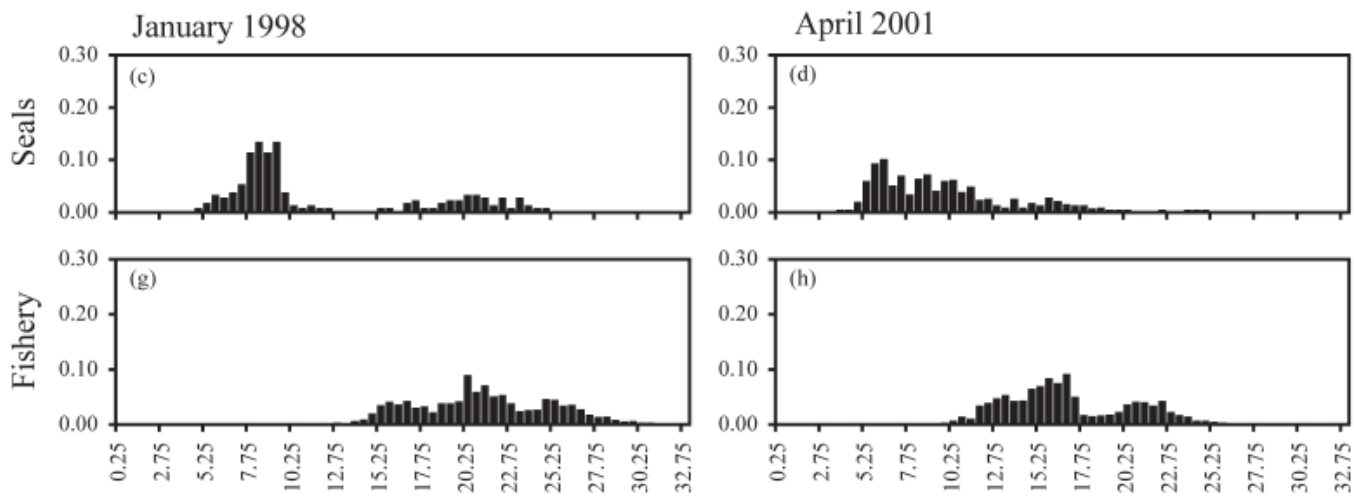

\section{Length class $(\mathrm{cm})$}

Fig. 3. Length-frequency distributions for Cape horse mackerel (a-d) consumed by Cape fur seals at Cape Cross and $(\mathrm{e}-\mathrm{h})$ caught by the purse-seine fishery within the study area in Namibia, for some months when $M$ was less than 0.25. Sample sizes, overlap measures $\left(S, M, S_{a d j}\right.$ and $\left.M_{a d j}\right)$ and their confidence intervals are given in Table 1.

Differences in techniques between seals and the fishery for obtaining horse mackerel may be the main explanation the observed low levels of overlap between them. For instance, selection of specific prey length classes by a predator, as well as capture avoidance by certain age classes of the prey targeted by a fishery, may lead to differences between predators and fisheries in the utilization of prey resource classes (Hill et al. 1996; Reid et al. 1996). It is unknown whether Cape fur seals select smaller horse mackerel than the fishery. Seals usually consume small fish that shoal (Mecenero et al.2006a), and because juvenile horse mackerel up to about $10 \mathrm{~cm}$ in length occur within shoals (Cruickshank 1983; Boyer \& Hampton 2001), small juveniles may be easy targets for seals. On the other hand, the purse-seine fishery mainly targets juveniles that are $12.5-20.0 \mathrm{~cm}$ in length (BaulethD'Almeida et al. 2001), the minimum size being mainly determined by the mesh size of the net used, although fish smaller than the mesh size may still be caught. Moreover, the purse-seine industry is required by regulation to stop fishing in an area if more than $5 \%$ of the catch, by weight, consists of fish less than $12.5 \mathrm{~cm}$ in length (MFMR 2002). Accordingly, purse-seine catches are biased towards juvenile fish greater than $12.5 \mathrm{~cm}$. This may explain why horse mackerel in age- 0 to age- 2 classes were found in the seal diet whereas the purse-seine fishery catch mainly comprised of age-2 $(15-17 \mathrm{~cm})$ horse mackerel. Large horse mackerel, greater than $25 \mathrm{~cm}$, also occur in shoals but in deeper waters. There, they are less accessible to seals, but they are also rarely targeted by the purse-seine fleet as they are more dispersed than juveniles, display greater net avoidance and generally are more difficult to catch by purse-seining (Bauleth-D'Almeida et al. 2001). 

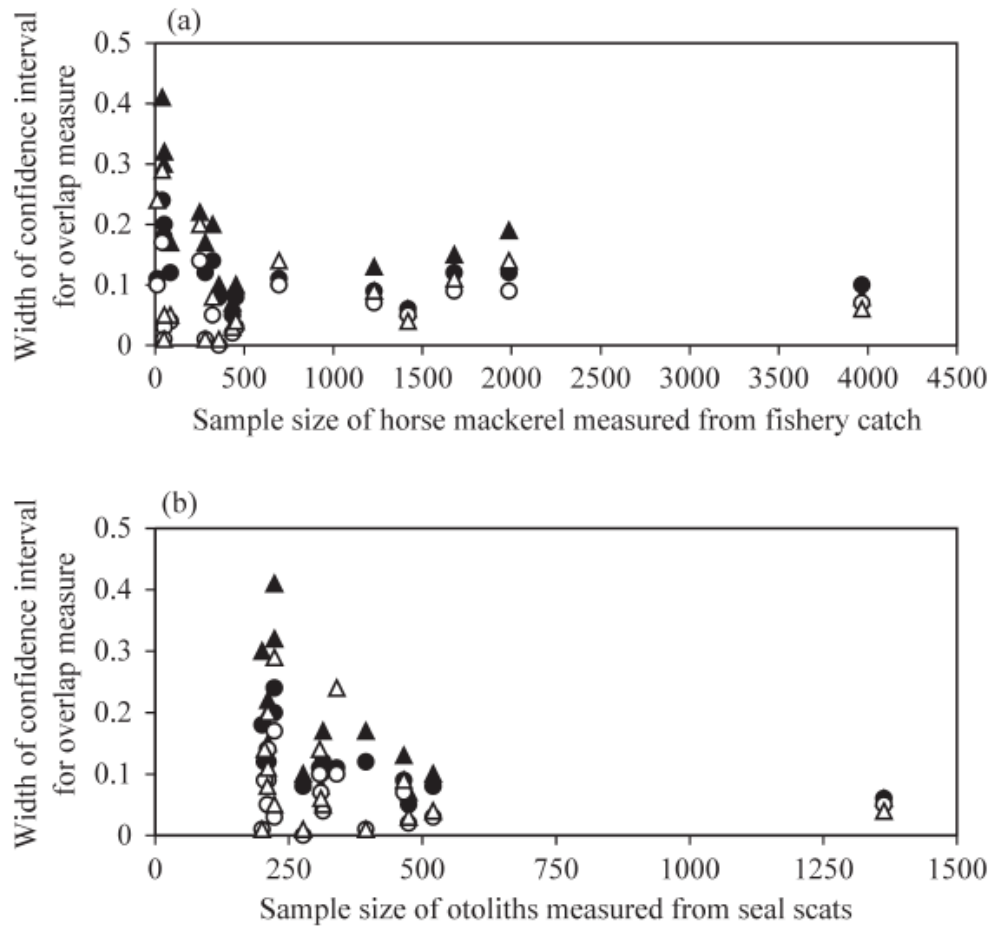

Fig. 4. The relationship between the width of the confidence interval for each overlap measure (๑ $S, \bigcirc S_{a d j} \boldsymbol{\Delta} M$, $\triangle M_{a d j}$ and the sample size of (a) Cape horse mackerel measured from the fishery catch within the study area and (b) otoliths measured from scat samples of Cape fur seals at Cape Cross.

Lactating females forage on locally abundant prey (Shaughnessy 1985; Oosthuizen 1991), therefore it was assumed that the proportion of horse mackerel in the diet of seals at Cape Cross reflected the abundance of this species within the foraging range of lactating females at Cape Cross. Subsequently, it was found that overlap measures (both unadjusted and adjusted) for the utilization of juvenile horse mackerel by seals and the fishery were high only when horse mackerel abundance was high. Because the fishery mainly caught age-2 horse mackerel due to constraints imposed by management, a high degree of overlap could have resulted from seals targeting older juvenile horse mackerel (age-2), either due to increased availability of this age class, or decreased availability of other prey, including younger age classes of horse mackerel. When horse mackerel abundance was low, overlap was small. This may be a result of horse mackerel migrating to deeper water as they mature, thus becoming inaccessible to seals (Krakstad \& Kanandjembo 2001; Axelsen et al. 2004), which switch to other more accessible prey such as hake and goby (Mecenero et al. 2006a). This pattern of a low degree of overlap between utilizers of prey when prey abundance is low is similar to that found by Croxall et al. (1999).

The present study used two overlap indices (Schoener's and Morisita's indices), which gave similar results. However, both indices are biased in that they ignore the variation in abundance of the resource classes (Hurlbert 1978; Petraitis 1979). In this study, the problem was addressed by adjusting the overlap indices by the relative abundance of horse mackerel in the seal diet. This was feasible because, as mentioned above, seals are opportunistic predators feeding on locally abundant prey (Shaughnessy 1985; Oosthuizen 1991). On the other hand, scat analysis has a number of limitations, and despite attempts to reduce the main biases (see Materials and Methods), horse mackerel abundance estimates from the seal diet may not have been entirely accurate. Unfortunately, the adjustment of the indices cannot be reliably verified by comparing diet data to horse mackerel abundance estimates obtained from surveys, because the acoustic surveys don't reliably detect horse mackerel less than $10 \mathrm{~cm}$, and therefore the age group consumed by seals is not reliably reflected in the survey results. 
One of the main pitfalls of overlap indices is that they do not include confidence limits. Monte Carlo simulations have been used in this regard for some overlap indices (Ricklefs \& Lau 1980). Confidence intervals permit further interpretation of overlap indices and provide information regarding their limitations. For this study, confidence intervals determined by bootstrapping showed that that a high degree of overlap (greater than 0.75 ) between seals and fisheries in their use of the horse mackerel resource was rare, whereas a low degree of overlap (less than 0.25) was more common. The smaller the confidence interval around the overlap measure, the more reliable the overlap measure (Sokal \& Rohlf 1995). This study showed that smaller confidence intervals (less than 0.20) resulted when seal diet and fishery catch sample sizes of measured horse mackerel were large (greater than 390 and 450, respectively). Sample sizes for both the fishery and seals for some months in this study were small (less than 50). The reliability of overlap indices would be improved by sampling larger amounts of the horse mackerel taken by seals and the fisheries.

Another drawback of overlap indices is that most of them do not provide the means of determining whether or not overlap is significant (Ricklefs \& Lau 1980; Zaret \& Smith 1984). In this study, significance levels determined by bootstrapping were useful in highlighting the fact that, in most cases (94\%), seals and fisheries were exploiting different size classes of the horse mackerel resource.

Overlap indices fail to measure competition because overlap is not linearly related to competition (Colwell \& Futuyma 1971; Hurlbert 1978), i.e. large values for the overlap index do not automatically represent direct competition, they may in fact imply reduced competition due to an abundance of the prey resource (Pianka 1974). The study by Plarre (1996), which investigated the overlap in utilization of horse mackerel by Cape fur seals and the purse-seine fisheries, concluded that there was 'competition' between the seals and the purseseine fishery for this prey. Plarre's (1996) study was based on Schoener's index, which is not a measure of competition because it does not include information on the static and dynamic properties of competition (Harwood \& Croxall 1988; Green et al. 1998). Static properties include fish distribution and abundance, as well as feeding effort, amount of fish utilized and size classes utilized by seals and fisheries in time and space. Dynamic properties include the response of fish to changes in predation rate, the response of seals, fisheries and other predators to changes in fish abundance, and the response of the market to fish supply. Unless all this information is incorporated into a competition index, then competition, defined as occurring when the concurrent presence of two competitors is mutually disadvantageous (Harwood \& Croxall 1988), between seals and fisheries cannot be determined. Usually it is impossible to provide all this information because it is either not available or difficult to obtain.

In conclusion, the results of this study showed that Cape fur seals and the horse mackerel purse-seine fisheries mostly take different resource classes of the horse mackerel stock, resulting in little overlap between them. However, because seals generally consumed smaller size classes than the fisheries, the fisheries may be affected by the proportion of small fish consumed by seals which would have become available to the fishery in the future. On the other hand, by taking bigger fish, the fishery may have an effect on the future recruitment of horse mackerel and therefore ultimately on what will become available to seals and the fishery in the future. Although it often seems reasonable to believe that reducing the number of seal predators would make more fish available to the fishery, this paper illustrates that the connection may not be so direct. The diet of the seals most of the time does not have a direct overlap with the fishery, and there is no guarantee that reducing the number of seal predators would make horse mackerel more available to the fishery, it may just increase the natural mortality rates of horse mackerel due to other causes (Butterworth 1992). For example, reducing Cape fur seal numbers may not enhance catches of Cape hakes to the fishery due to feedback control: shallow-water hake Merluccius capensis preys on deep-water hake $M$. paradoxus, and depending on the degree to which seals consume shallow-water hake, a reduction in seal numbers may negatively affect deep-water hake fisheries (Punt \& Butterworth 1995).

This overlap study provides important insights into the interactions between Cape fur seals and the purse-seine fishery, which should be considered in the management of the horse mackerel stock. Abundance data on the first age class of horse mackerel are not available from the acoustic survey nor from the commercial catches. Therefore, once a reliable recruitment index has been established from the scats the data can be implemented into the age-based production model used 
by the Namibian Ministry of Fisheries to assess the horse mackerel stock. These additional data may improve the model by more accurately predict the juvenile age classes of horse mackerel and their early recruitment to the purse seine fishery.

\section{ACKNOWLEDGEMENTS}

This study is part of the Namibian Ministry of Fisheries and Marine Resources' (MFMR) ongoing investigation of the diet of the Cape fur seal population in Namibia. The seal diet sampling and processing was undertaken by researchers and technicians of the Marine Mammal Section at the MFMR, and the Pelagic and Demersal Sections assisted in collecting samples at Cape Cross; special thanks go to K.T. Kleophas and N. Mukapuli. Logistical support was provided by the MFMR. The project was supported by a National Research Foundation (NRF) prestigious bursary to S.M., and L.G.U. acknowledges support from the NRF and the University of Cape Town.

\section{REFERENCES}

ABRAMS, P. 1980. Some comments on measuring niche overlap. Ecology 61: 44-49.

ANON. 2000. Report of the horse mackerel age-determination workshop, Swakopmund, Namibia, 30 May 8 June 2000 (19 pp.). BENEFIT, Swakopmund, Namibia.

AXELSEN, B.E., KRAKSTAD, J-O. \& BAULETHD'ALMEIDA, G. 2004. Aggregation dynamics and diel vertical migration in Cape horse mackerel (Trachurus trachurus capensis) in the Namibian Benguela. Implications for acoustic abundance estimation. In: U.R. Sumaila, S.I. Steinshamn, M.D. Skogen \& D. Boyer (Eds), Ecological, economic and social aspects of Namibian fisheries (pp. 135-164). Eburon, Delft.

BAULETH-D'ALMEIDA, G., KRAKSTAD, J-O. \& KANANDJEMBO, A. 2001. Comparison of horse mackerel length frequencies obtained from research vessels and commercial midwater trawlers: implications for biomass estimation. S. Afr. J. Mar. Sci. 23: 265-274

BOYER, D.C. \& HAMPTON, I. 2001. An overview of the living marine resources of Namibia. S. Afr. J. Mar. Sci. 23: 5-35.

BUTTERWORTH, D.S. 1992. Will more seals result in reduced fishing quotas? S. Afr. J. Sci. 88: 414-417.

COLWELL, R.K. \& FUTUYMA, D.J. 1971. On the measurement of niche breadth and overlap. Ecology 52: 567-576.

CRAWFORD, R.J.M., UNDERHILL, L.G., RAUBENHEIMER, C.M., DYER, B.M. \& MARTIN, J. 1992. Top predators in the Benguela ecosystem. Implications of their trophic position. S. Afr. J. Mar. Sci. 12: 675-687.

CROXALL, J.P., REID, K. \& PRINCE, P.A. 1999. Diet, provisioning and productivity responses of marine predators to differences in availability of Antarctic krill. Mar. Ecol. Prog. Ser. 177: 115-131.
CRUICKSHANK, R.A. 1983. Distribution of pelagic fish shoals determined by acoustic surveys in 1981-1982 and its relationship to environmental factors. Colln. Scient. Pap. Int. Commn. SE Atl. Fish. 10: 75-97.

CURRIE, R. 1953. Upwelling in the Benguela current. Nature 171: 497-500.

DAVID, J.H.M. 1987. Diet of the South African fur seal (1974-1985) and an assessment of competition with fisheries in southern Africa. S. Afr. J. mar. Sci. 5: 693-713.

DELLINGER, T. \& TRILLMICH, F. 1988. Estimating diet composition from scat analysis in otariid seals (Otariidae): is it reliable? Can. J. Zool.66: 1865-1870.

DELLINGER, T. \& TRILLMICH, F. 1999. Fish prey of the sympatric Galápagos fur seals and sea lions: seasonal variation and niche separation. Can. J. Zool.77: 1204-1216.

GOLDSWORTHY, S.D., HE, X., TUCK, G.N., LEWIS, M. \& WILLIAMS, R. 2001. Trophic interactions between Patagonian toothfish, its fishery, and seals and seabirds around Macquarie Island. Mar. Ecol. Prog. Ser. 218: 283-302.

GREEN, K., SLIP, D.J. \& MOORE, G.J. 1998. The take of fish species by seabirds and marine mammals in the Australian fisheries zone around Heard Island: the potential for competition with a commercial fishery. Polar Biol. 20: 273-280.

HÄRKÖNEN, T. 1988. Food-habitat relationship of harbour seals and black cormorants in Skagerrak and Kattegat. J. Zool., Lond. 214: 673-681.

HARWOOD, J. \& CROXALL, J.P. 1988. The assessment of competition between seals and commercial fisheries in the North Sea and the Antarctic. Mar. Mamm. Sci. 4: 13-33.

HILL, H.J., TRATHAN, P.N., CROXALL, J.P. \& WATKINS, J.L. 1996. A comparison of Antarctic krill Euphausia superba caught by nets and taken by macaroni penguins Eudyptes chrysolophus: evidence for selection? Mar. Ecol. Prog. Ser. 140: 1-11.

HUNT, G.L.Jr., KITAYSKY, A.S., DECKER, M.B., DRAGOO, D.E. \& SPRINGER, A.M. 1996. Changes in the distribution and size of juvenile walleye pollock, Theragra chalcogrammu, as indicated by seabird diets at the Pribilof Islands and by bottom trawl surveys in the Eastern Bering Sea, 1975 to 1993. US Dept. Commer. NOAA Tech. Rep. NMFA 126: 125-139.

HURLBERT, S.H. 1978. The measurement of niche overlap and some relatives. Ecology 59: 67-77.

KLAGES, N.T.W., WILLIS, A.B. \& ROSS, G.J.B. 1992. Variability in the diet of the Cape gannet at Bird Island, Algoa Bay, South Africa. S. Afr. J. Mar. Sci. 12: 761-771.

KOOYMAN, G.L. \& GENTRY, R.L. 1986. Diving behavior of South African fur seals. In: R.L. Gentry \& G.L. Kooyman (Eds), Fur seals: maternal strategies on land and at sea (pp. 142-152). University Press, Princeton, New Jersey.

KRAKSTAD, J-O. \& KANANDJEMBO, A. 2001. A summary of the fishery and biology of Cape horse mackerel in Namibian waters. In: J-O. Krakstad, F. Botes \& A. Kanandjembo (Eds), The research and management of horse mackerel in Namibian waters. Ministry of Fisheries and Marine Resources, Swakopmund, Namibia. 
LLOYD, M. 1967. Mean crowding. J. Anim. Ecol.36: 1-30.

LOWRY, L.F. \& FROST, K.J. 1985. Biological interactions between marine mammals and commercial fisheries in the Bering Sea. In: J.R. Beddington, R.J.H. Beverton \& D.M. Lavigne (Eds), Marine mammals and fisheries (pp. 41-61). George Allen and Unwin, London.

MANLY, B.F.J. 1991. Randomization and Monte Carlo methods in biology. Chapman and Hall, London.

MECENERO, S., ROUX, J-P., UNDERHILL, L.G. \& BESTER, M.N. 2006a. The diet of Cape fur seals Arctocephalus pusillus pusillus at three mainland breeding colonies in Namibia. 1. Spatial variation. Afr. J. Mar. Sci. 28: 57-71.

MECENERO, S., ROUX, J-P., UNDERHILL, L.G. \& KIRKMAN, S.P. 2006b. The diet of Cape fur seals Arctocephalus pusillus pusillus at three mainland breeding colonies in Namibia. 2. Temporal variation. S. Afr. J. Mar. Sci. 28: 73-88.

MINISTRY OF FISHERIES AND MARINE RESOURCES 2002. Management recommendations for horse mackerel, rock lobster and crab based on the biological state of the stock. Report for the Marine Resources Advisory Council No. 3, Windhoek.

MONTEVECCHI, W.A. \& MYERS, R.A. 1995. Prey harvests of seabirds reflect pelagic fish and squid abundance on multiple spatial and temporal scales. Mar. Ecol. Prog. Ser. 117: 1-9.

MORISITA, M. 1959. Measuring of interspecific association and similarity between communities. Mem. Fac. Sci. Kyushu Univ. Ser. E 3: 64-80.

OOSTHUIZEN, W.H. 1991. General movements of South African (Cape) fur seals Arctocephalus pusillus pusillus from analysis of recoveries of tagged animals. S. Afr. J. Mar. Sci. 11:21-29.

ORR, A.J. \& HARVEY, J.T. 2001. Quantifying errors associated with using fecal samples to determine the diet of the California sea lion (Zalophus californianus). Can. J. Zool. 79: 1080-1087.

O'TOOLE, M.J. 1977. Investigations into some important fish larvae in the South East Atlantic in relation to the hydrological environment. Ph.D. dissertation, University of Cape Town, South Africa.

PETRAITIS, P.S. 1979. Likelihood measures of niche breadth and overlap. Ecology 60: 703-710.

PIANKA, E.R. 1973. The structure of lizard communities. Ann. Rev. Ecol. Syst. 4: 53-74.

PIANKA, E.R. 1974. Niche overlap and diffuse competition. Proc. Nat. Acad. Sci. USA 71: 2141-2145.

PIERCE, G.J. \& BOYLE, P.R. 1991. A review of methods for diet analysis in piscivorous marine mammals. Oceanogr. Mar. Biol. Ann. Rev. 29: 409-486.

PLARRE, H. 1996. Purse seiners and seals: to what degree do they compete for horse mackerel? B.Sc. (Hons) dissertation, University of Potchefstroom, South Africa.

PUNT, A.E. \& BUTTERWORTH, D.S. 1995. The effects of future consumption by the Cape fur seal on catches and catch rates of the Cape hakes. 4. Modelling the biological interaction between Cape fur seals Arctocephalus pusillus pusillus and the Cape hakes Merluccius capensis and M. paradoxus. S. Afr. J. Mar. Sci. 16: 255-285.
PUNT, A.E., DAVID, J.H.M. \& LESLIE, R.W. 1995. The effects of future consumption by the Cape fur seal on catches and catch rates of the Cape hakes. 2. Feeding and diet of the Cape fur seal Arctocephalus pusillus pusillus. S. Afr. J. Mar. Sci. 16: 85-99.

RAND, R.W. 1959. The Cape fur seal (Arctocephalus pusillus). Distribution, abundance and feeding habits off the south western coast of the Cape Province. Investl. Rep. Div. Fish. S. Afr. 34: 1-75.

REID, K., TRATHAN, P.N., CROXALL, J.P. \& HILL, H.J. 1996. Krill caught by predators and nets: differences between species and techniques. Mar. Ecol. Prog. Ser. 140: 13-20.

REID, K., WATKINS, J.L., CROXALL, J.P. \& MURPHY, E.J. 1999. Krill population dynamics at South Georgia 1991-1997, based on data from predators and nets. Mar. Ecol. Prog. Ser. 177: 103-114.

RICKLEFS, R.E. \& LAU, M. 1980. Bias and dispersion of overlap indices: results of some Monte Carlo simulations. Ecology 61: 1019-1024.

SCHOENER, T.W. 1970. Nonsynchronous spatial overlap of lizards in patchy habitats. Ecology 51:408-418.

SHAUGHNESSY, P.D. 1985. Interactions between fisheries and Cape fur seals in southern Africa. In: J.R. Beddington, R.J.H. Beverton \& D.M. Lavigne (Eds), Marine mammals and fisheries (pp. 119-134). George Allen and Unwin, London.

SHANNON, L.J. \& JARRE-TEICHMANN, A. 1999. A model of trophic flows in the northern Benguela upwelling system during the 1980s. S. Afr. J. Mar. Sci. 21: 349-366.

SMALE, M.J., WATSON, G. \& HECHT, T. 1995. Otoliths of Southern African marine fishes. Ichthyological Monographs 1. J.L.B. Smith Institute of Ichthyology, Grahamstown, South Africa.

SMITH, E.P. \& ZARET, T.M. 1982. Bias in estimating niche overlap. Ecology 63: 1248-1253.

SOKAL, R.R. \& ROHLF, F.J. 1995. Biometry: the principles and practice of statistics in biological research, 3rd edn. W.H. Freeman and Company, New York.

STANILAND, I.J. 2002. Investigating the biases in the use of hard prey remains to identify diet composition using Antarctic fur seals (Arctocephalus gazella) in captive feeding trials. Mar.Mamm. Sci. 18:223-243.

TOLLIT, D.J. \& THOMPSON, P.M. 1996. Seasonal and between-year variations in the diet of harbour seals in the Moray Firth, Scotland. Can. J. Zool. 74: 11101121.

WATHNE, J.A., HAUG, T. \& LYDERSEN, C. 2000. Prey preference and niche overlap of ringed seals Phoca hispida and harp seals P. groenlandica in the Barents Sea. Mar. Ecol. Prog. Ser. 194: 233-239.

WICKENS, P.A., JAPP, D.W., SHELTON, P.A., KRIEL, F., GOOSEN, P.C., ROSE, B., AUGUSTYN, C.J., BROSS, C.A.R., PENNEY, A.J. \& KROHN, R.G. 1992. Seals and fisheries in South Africa - Competition and conflict. S. Afr. J. Mar. Sci. 12: 773-789.

ZARET, T.M. \& SMITH, E.P. 1984. On measuring niches and not measuring them. In: T.M. Zaret (Ed.), Evolutionary ecology of neotropical freshwater fishes (pp. 127-137). W Junk, The Hague. 